UDC: 37.014

DOI: https://doi.org/10.24195/2414-4665-2017-5-10

\author{
Olena Kovshar, \\ Doctor of Pedagogy, associate professor, \\ head of the Department of Preschool Education, \\ Kryvyi Rih State Pedagogical University, \\ 54, Haharyna Avenue, Kryvyi Rih, Ukraine
}

\title{
NEW FORMATIONS OF SENIOR PRESCHOOL CHILDREN AS THE BASIS FOR FORMING THEIR SOCIAL POSITION OF SCHOOL STUDENTS
}

The main task of contemporary preschool education is creating conditions for the development of children's capabilities, improvement of their uniqueness and preparation for further education. The aim of the paper is to analyse the development of senior preschool children's new formations and their role in the development of children's readiness for schooling. The most important new formations of this age are the following: hierarchy of motives, development of social motives of behaviour and activity, which will determine learner's inner attitude; development of "internal ethical instantiations", the level of conscious mental processes development along with such volitional qualities as independence, initiative and responsibility, which prepare five-year-old children for the new social position. As part of the empirical study, the levels of five-year-old children's readiness for schooling (the creative, productive and elementary ones) based on the acquired new formations have been identified. According to the results obtained, the methodology intended for the formation of the new social position of a schoolchild in senior preschool children, which involved various forms of work with children, their parents and teachers (preschool and primary school teachers), was implemented and tested. Repeated evaluation of the above-mentioned criteria demonstrated the effectiveness of the developed experimental methodology: the creative level of the formation of the new social position of a schoolchild was observed among $30.5 \%$ of the EG participants and 5.5\% of CG participants; the productive level - $62.5 \%$ in the EG and $37.5 \%$ in the CG; the elementary level was demonstrated by $7 \%$ of EG participants and $57 \%$ of the CG participants.

Keywords: hierarchy of motives, internal attitude of a schoolchild, internal ethical instantiations, consciousness of mental process, independence, initiative, readiness for schooling, social position of a schoolchild, new social attitude of a schoolchild.

\section{Introduction}

The main priority of contemporary education is a child's personality. Creating conditions for the development of his/her uniqueness and capabilities will contribute to his/her successful work in future, which in its turn will have positive impact on prosperity of the state.

Preschool education is the initial segment of general education. Basic principles of the Ukrainian system of preschool education are declared in the series of national legal documents, namely The State National Programme "Education" (Ukraine, XXI century), the Laws "On Preschool Education", “On Child Protection”, Basic Component of Preschool Education.

The transition from preschool childhood to the school one is characterised by drastic changes of a child's place in the system of corresponding social relations and his/her lifestyle in general.

According to L. Vyhotskyi, to be ready for schooling means to achieve a certain level of intellectual processes: a child must be able to distinguish the main points of the surrounding phenomena, compare, comprehend, and draw conclusions. A child who cannot follow a teacher's narration and draw simple conclusions is not ready for schooling [5, p. 384]. This opinion was shared by L. Venher who emphasised that a child's readiness for schooling involves his/her capability for differentiated perception, elementary forms of logical memorising, logical thinking, reproductive imagination $[4$, p. 34$]$.

L. Bozhovych notes that a preschool child must have the developed level of cognitive attitude towards the reality, the level of the development cognitive interests and needs - the need for acquiring new knowledge and abilities, which is fulfilled in learning as a socially significant activity and forms a new social postition [3, p. 227].

O. Leontiev notes that child's understanding of the content of tasks, their difference from the practical ones, his/her knowledge of techniques of performing actions, self-control and self-evaluation skills; the development of volitional qualities, the ability to observe, listen, memorise, try to solve problems; the ability to control his/her behaviour contribute to the formation of the new social position - "a schoolchild".

Thus, the social position "a schoolchild" involves child's understanding of techniques of performing actions, self-control and self-evaluation skills, the development of volitional qualities, hierarchy of motives, the development of social motives of behaviour and activity, which will determine schoolchild's inner attitude in future.

Among the new formations peculiar to this age we would like to highlight the hierarchy of motives and the development of social motives of behaviour and activity. The research works by O. Leontiev and K. Hurevych 
proved that the hierarchy of motives is a new formation typical for senior preschool age [8]. O. Leontiev came to a conclusion that it is at preschool age when conscious and autonomous subordination of one child's action to another occurs for the first time, i. e. his/her personality is being developed. There appears a new relation between motives and child's ability to consciously subordinate his/her actions to more important and distant goals, though they may seem unattractive to him/her [8, p. 281]. It is an important prerequisite for preschool child's future schooling [3, p. 240].

L. Vyhotskyi considers the emergence of "internal ethical instantiations" to be one of the new formations of preschool childhood [4, p. 625]. D. Elkonin associates their emergence with the formation of a new type of relationships between a child and an adult. An adult becomes an example for a child. The formation of the first ethical ideas is the process of the acquiring of new behavioural patterns associated with adults' appraisal. A child acquires a new type of behaviour, which can be called the individual one [5, p. 380-381].

The researchers (V. Davydov, O. Zaporozhets, D. Elkonin, V. Kotyrlo et al.) emphasise that one of the psychic new formations of senior preschoolers is developed consciousness of psychic processes: from the age of 5 to 7 actions, deeds and behaviour in general become consciously controlled. L. Bozhovych thinks that a new formation is expressed in preschool child's willing not only to act in accordance with moral motives, but also refuse from things that are attractive for him/her $[3, \mathrm{p}$. 240]. As noted by T. Pirozhenko, mastering the ability to regulate behaviour consciously is the most significant indicator of general development and readiness for schooling [9, p. 10].

V. Kotyrlo confirms that conscious character of senior preschoolers' behaviour is expressed in the ability to direct their psychic activity and control themselves according to the requirements of a certain task and activity in general, rules of conduct, moral norms corresponding to the age of a child $[7$, p. 40]. It means that a child uses effort of will to stop doing what he/she wants to do and perform some other actions even if he/she does not want to, H. Bielienka notes [1, p. 11]. Conscious behaviour is expressed in overcoming obstacles, either internal or external. It occurs when a child, being captured by some goals that are important for him/her, is trying to fulfil them using some efforts. For example, such volitional qualities as independence, initiative and responsibility are being developed, V. Kotyrlo thinks [7, p. 40].

Independence is an integrated personal quality, which is expressed in initiative, criticism, reasonable selfesteem and responsibility for the consequences of one's actions and behaviour. It is the ability to set a goal and achieve it, to solve problems using one's own resources [1, p. 11]. Independence as a basic personal quality has two principle components - freedom of choice and the ability to be responsible for it. The level of child's independence corresponds to his/her age in case he/she is able to make decisions and find ways to achieve goals in his/her playing activity.

Due to the level of the above-mentioned mental processes development and maturity, a child has new opportunities to express his/her "self" in all kinds of activity. $\mathrm{He} / \mathrm{she}$ can not only perform actions according to the example, but use some creativity. It is worth noting that creativity is the level of creative giftedness, creative capabilities, which are expressed in thinking, communication, some kinds of activity and form a relatively stable characteristics of a personality. Creativity is a child's capability for creative work, readiness to perceive and generate extraordinary ideas; quick-wittedness, ingenuity [1, p. 12]

Preschooler's desire to be a schoolchild is one of the leading motives for entering a school, which determines his/her readiness for schooling and learning. Senior preschooler's readiness for a new social position involves corresponding level of development of social motives of behaviour and activity [3, p. 216-217]. According to L. Bozhovych, social motives include "child's need for communication with other people, their assessments and recognition; preschool child's willing to take a certain place in the system of social relations that are available to him/her" [3, p. 311].

The scientists A. Venher, D. Elkonin, T. Niezhnova consider the concept "social position of a schoolchild" as a system of needs and intents associated with school, when involvement into schooling becomes child's own necessity. This very social position (a schoolchild) is the basis for the formation of a future first-grader as a student, which is characterised by peculiarities of child's psyche, namely gradual transition from self-centred to socio-centred worldview; from ideal Self to the real one; the formation of self-esteem. A child is learning how to communicate with him-/herself, understand him-/herself and subordinate his/her desires and feelings to new external norms and requirements [4, p. 34].

Thus, five-year-old children's readiness for the new social position of schoolchildren is understood as the maturity of basic qualities peculiar to an integrated personality; the development of all psychic processes corresponding to this age group as well as cognitive and speech activity; the formation of qualitative psychic new formations: moral and ethical instantiations, conscious behaviour, independence and responsibility, creativity, initiative, autonomy of behaviour, self-esteem, self-attitude, self-consciousness.

The paper aims to analyse the development of senior preschool children's new formations and determine their role in forming social position of a schoolchild and readiness for schooling.

\section{Research methods}

For empirical study of the development of senior preschool children's new formations, their new social position of schoolchildren, as well as assessment of children's readiness for schooling, the experimental work has been carried out. It involved preschool educational institu- 
tions of Dnipro and Odessa regions. Participants of the empirical study were children of senior preschool age, their parents and teachers of the cities of Kryvyi Rih and Odessa.

The study involved 750 children attending senior groups of the above-mentioned preschool institutions (the control group (CG) consisted of 382 children and the experimental one (EG) involved 368 children) as well as 250 preschool and primary school teachers.

\section{Discussion}

Based on the analysis of the acquired new formations, the levels of senior preschoolers' readiness for the new social position of schoolchildren have been distinguished - the creative, productive and elementary ones. The corresponding methodology for the formation of the new social attitude has been developed and implemented.

It has been found that the children with the creative level identify themselves with their own "Self", their places in the system of interaction, have positive perception of the society and meaningful cooperation with their equals in age; are able to control expression of their emotions and disposition; have reasonable self-esteem; are familiar with social norms of living together and able to use the acquired knowledge in various life circumstances; know moral norms and rules of relationships with other people.

The productive level is characterised by positive worldview; the children are familiar with social norms, but are not always able to use acquired knowledge in reallife situations and build relationships without conflicts; they demonstrate piecewise knowledge of norms and rules of conduct and benevolence; are sometimes unable to choose appropriate means of communication with other people; they have reasonable self-esteem, know moral and ethical norms, but sometimes identify them incorrectly; they do not give reasons for their evaluations.

The children with the elementary level do not identify themselves with their own "Self", feel suspicious about the society, do not initiate their own actions, try to avoid contact with their equals in age and adults, act according to instructions; they have superficial knowledge of social norms of behaviour; are characterised by mostly changeable uncontrolled mood and unreasonable self-esteem.

In order to identify the levels of five-year-old children's readiness for their new social position of schoolchildren, we have implemented a series of diagnostic tasks in the control and experimental groups: didactic exercises "The world through the eyes of children", "Estimate your emotions", "The good or the bad", "Three words about yourself"; conversational games "Don't waste your time, help your family", "The guide", "Conversational partner", "I ask, you answer"; conversational exercises "How should we say?", "Preschoolers are polite children", "Establishing friendly relationships with equals in age", "My friends and I at the kindergarten", individual interviews.

According to the analysis of children's performing of the tasks, the following results have been obtained: the creative level of preschool children's readiness for the new social position of schoolchildren was demonstrated by $2.5 \%$ of children from the EG and $3.5 \%$ of the $\mathrm{CG}$ participants; the productive level - among $39.5 \%$ of EG participants and $39 \%$ of the children from CG; the elementary level was observed in 58\% of the EG participants and $57.5 \%$ of the CG participants.

The methodology intended for the formation of the social position of a schoolchild in senior preschool children involved various forms of work with children, their parents and teachers (preschool and primary school teachers).

The methodology was implemented by means of the following events: planning the work of teachers and methodological services in terms of the formation of future first-graders' new social position of schoolchildren; cooperative pedagogical round table discussions ("The unity, interaction and conformity of forms, methods and techniques of educational work with children of five years old and primary school age"), pedagogical counselling, seminars-workshops ("Problems of five-year-old children's adaptation to schooling", "Ways of preventing children's disadaptation in learning"), business games ("Adaptation of kindergarten graduates to new conditions of school life: problems and ways of their solving").

Parent-teacher conferences were held for parents of future first-graders ("A preschooler today and a firstgrader tomorrow", "When your child is going to school", "Having a future fist-grader in a family", "Do we know our own child?"), meetings of parent clubs ("Ways of acquiring the new social position of a schoolchild by fiveyear-old children", "Intellectual games and tasks of upbringing children"), "boxes" for questions and suggestions, library with videos concerning various problematic issues, web-sites for parents, training sessions on the issues of preparing children for acquiring the new social position of schoolchildren ("New social conditions for first-graders", "Self-esteem as a component of child's readiness for the new social status of a schoolchild", "How to overcome lack of self-confidence and shyness?"), pedagogical lectures for parents ("The formation of responsibility in children as an important personal quality for further schooling"), thematic boards and folders ("Ways of forming cognitive interest in learning among children", "Important independent living skills, peculiarities of their formation and improvement", "Rules for instilling self-confidence"), etc.

Also, the formation of five-year-old children's readiness for the new social position was possible due to the following forms of educational process organisation: a series of classes ("I feel the world", "Fairy tales about the power of the Good", "Kindness is the uppermost virtue", "Every person is unique", "You are living among people"), integrated classes with the elements of designing ("What am I?", "My friends", "Creating a cartoon fairy tale", "My family"); training for future first-graders "I am a future first-grader"; games intended for the development of elementary skills of learning activity ("The dwarf's 
house", "Pigtails", "Flowers and snowflakes", "Hit the mark"); socio-communicative and game situations ("I am a schoolchild", "My attitude to my friends", "My future school friends", "How I imagine myself in a classroom", "Getting education will help you see the world", "Being at school on the bell", "My future school", etc.).

To assess the effectiveness of the proposed methodology according to the specified criteria and indicators, the level of development of the new social position of a schoolchild among five-year-old children was evaluated again and the results were compared to the obtained before.

The following changes were observed in the experimental group compared to the control one: the creative level of the formation of the new social status of a schoolchild was observed among $30.5 \%$ of the EG participants and $5.5 \%$ of $\mathrm{CG}$ participants; the productive level $62.5 \%$ in the EG and $37.5 \%$ in the CG; the elementary level was demonstrated by $7 \%$ of EG participants and $57 \%$ of the CG participants.

\section{REFERENCES}

1. Bielienka, H. V. (2015). Osobystist vypusknyka dytsadka: bazovi yakosti [Personality of a preschool institution graduate: basic qualities]. Doshkilne vykhovannia Preschool education, 7, 11-14 [in Ukrainian].

2. Bekh, I. (2015). Zrostyty moralnu osobystist holovna turbota [Upbringing a moral personality as the major concern]. Doshkilne vykhovannia - Preschool education, 4, 6-8 [in Ukrainian].

3. Bozhovich, L. I. (1968). Lichnost i ee formirovanie $\mathrm{v}$ detskom vozraste [Personality and its formation at preschool age]. Moscow: Prosveshchenie [in Russian].

4. Venger, L. A. (1972). Ob urovne razvitiia detei, postupaiushchikh $\mathrm{v}$ shkolu [The level of development of children starting school]. Doshkilne vykhovannia - Preschool education, 8, 33-38 [in Russian].

5. Vygotskii, L. S. (1984). Krizis semi let [Crisis of seven years of age]. (Vols. 4). Moscow: Pedagogika [in Russian].

\section{ЛІТЕРАТУРА}

1. Бєлєнька Г. В. Особистість випускника дитсадка : базові якості / Г. В. Бєлєнька // Дошкільне виховання. - 2015. - № 7. - С. 11-14.

2. Бех І. Зростити моральну особистість - головна турбота / I. Бех // Дошкільне виховання. - 2015. № 4. - С. 6-8.

3. Божович Л. И. Личность и ее формирование в детском возрасте / Л. И. Божович. - Москва : Просвещение, 1968. - 464 с.

4. Венгер Л. А. Об уровне развития детей, поступающих в школу / Л. А. Венгер // Дошкольное воспитание. - 1972. - № 8. - С. 33-38.
Therefore the results obtained prove the effectiveness of the developed experimental methodology for the formation of the new social position "a schoolchild" among five-year-old children.

\section{Conclusions}

Theoretical review of the literature has made it possible to conclude that the most important new formations of children of senior preschool age, which form the social position of a schoolchild are as follows: child's understanding of techniques of performing actions, self-control and self-evaluation skills, volitional qualities development, hierarchy of motives, the development of social motives of behaviour and activity, which will determine a schoolchild's inner attitude in future.

The proposed methodology indented for the formation of five-year-old children's readiness for schooling (according to the acquired new formations peculiar to this age group) has proven to be effective.

Further study should be aimed at the issues of providing pedagogical conditions for children's adaptation to schooling.

6. Derkach, O. (2013). Ya - shkoliar [I am a schoolchild]. Doshkilne vykhovannia - Preschool education, 2, 12-13 [in Ukrainian].

7. Kotyrlo, V. (1979). Razvitie volevogo povedeniia $\mathrm{u}$ doshkolnikov [Development of volitional behaviour in preschool children]. Kyiv: «Radianska shkola» [in Russian].

8. Leontev, A. N. (1983). K teorii razvitiia psikhiki rebenka [The theory of preschool child's psyche development]. Izbrannye psikhologicheskie proizvedeniia Selected works on psychology. (Vol. 1). Moscow: Pedagogika [in Russian].

9. Pirozhenko, T. (2012). Chomu «halmuie» doshkilna zrilist? [Why does preschool maturity retard?]. Vykhovatel-metodyst doshkilnoho zakladu - Educator of a preschool institution, 7, 9-12 [in Ukrainian].

10. Proskura, O. V. (1998). Psykholohichna pidtrymka vchytelia do roboty iz pershoklasnykamy [Psychological support for teachers working with first-graders]. Kyiv [in Ukrainian].

5. Выготский Л. С. Кризис семи лет : соб. соч. в 6 т. - Том 4 / Л. С. Выготский; - М. : Педагогика, 1984. - C. 376-385.

6. Деркач О. Я - школяр / О. Деркач // Дошкільне виховання. - 2013. - № 2. - С. 12-13.

7. Котырло В. Развитие волевого поведения у дошкольников / В. Котырло. - К. : «Рад. школа», 1979. - C. 39-41.

8. Леонтьев А. Н. К теории развития психики ребенка / А. Н. Леонтьев // Избранные психологические произведения : в 2 т. - Москва : Педагогика, 1983. - Т. 1. - C. 281-302. 
9. Піроженко Т. Чому «гальмує» дошкільна зрілість? / Т. Піроженко // Вихователь-методист дошкільного закладу. - 2012. - № 7. - С. 9-12.
10. Проскура О. В. Психологічна підтримка вчителя до роботи із першокласниками / О. В. Проскура. - Київ, 1998. - С. 70.

Олена Вікторівна Ковщар, доктор педагогічних наук, доцент, завідувач кафедри дошкільної освіти Криворізький державний педагогічний університет, пр. Гагарина, 54, м. Кривий Ріг, Украӥна

\section{НОВОУТВОРЕННЯ СТАРШИХ ДОШКІЛЬНИКІВ ЯК УМОВА ФОРМУВАННЯ СОЦАЛЬНОЇ ПОЗИЦІї «ШКОЛЯР»}

Головним завданням сучасної дошкільної освіти є створення умов для розвитку здібностей та обдарувань дитини, удосконалення її неповторної унікальності, підготовка до подальшого навчання. Мета статті - проаналізувати процес формування новоутворень дітей старшого дошкільного віку та їх роль у набутті дітьми готовності до шкільного навчання. Серед новоутворень саме цього віку особливо цінними $є$ супідрядність мотивів, розвиток соціальних мотивів поведінки та діяльності, які надалі будуть визначати внутрішню позицію учня; виникнення в цей період у дитини «внутрішніх етичних інстанцій», сформованість довільності психічних процесів, а також таких вольових якостей, як самостійність, ініціативність та відповідальність, що готують дитину шестирічного віку до нового соціального статусу. За аналізом набутих новоутворень п'ятирічними дітьми, які відвідують дошкільні навчальні заклади м. Дніпра та Одеси, виділено рівні готовності дітей старшого дошкільного віку до нової соціальної позиції «школяр» (творчий, продуктивний, елементарний); розроблено і реалізовано відповідну методику формування соціальної позиції «школяр». Зазначена методика включала різноманітні форми роботи з дітьми, їхніми батьками та педагогами (вихователями та вчителями початкових класів). За результатами повторного оцінювання рівнів готовності до нової соціальної позиції «школяр», в експериментальній групі відбувалися позитивні зміни порівняно з контрольною групою. Творчий рівень сформованості соціальної позиції «школяр» на прикінцевому етапі було зафіксовано у 30,5\% дітей ЕГ (було 2,5\%) i 5,5\% - у КГ (було 3,5\%); на продуктивному рівні в ЕГ стало 62,5\% (було 39,5 \%) дошкільників, у КГ - 37,5\% (було 39\%); на елементарному рівні залишилося в ЕГ - 7\% (було 58\%) дітей, у КГ - 57\% (було 57,5\%). Отримані дані підтвердили ефективність розробленої експериментальної методики формування соціальної позиції «школяр» у дітей п’яти років.

Ключові слова: супідрядність мотивів, внутрішня позиція учня, внутрішні етичні інстанції, довільність психічних процесів, самостійність, ініціативність, готовність до навчання у школі, соціальний статус «школяра», нова соціальна позиція «школяр». 